\title{
Nutritional value of high and low tannin high-moisture sorghum grain silage in horses ${ }^{1}$
}

\section{Augusta Martins Romaniello Gollcher², José Augusto de Freitas Lima ${ }^{3}$, Elias Tadeu Fialho ${ }^{3}$, Paulo Borges Rodrigues ${ }^{3}$, Renato Ribeiro de Lima $^{4}$}

\author{
1 Pesquisa financiada pela CAPES. \\ 2 Programa de Pós-graduação em Zootecnia - UFLA, Caixa Postal 3037, CEP: 37.200-000 - Lavras, MG. \\ ${ }^{3}$ Departamento de Zootecnia/UFLA, Caixa Postal 3037, CEP: 37.200-000 - Lavras, MG. \\ ${ }^{4}$ Departamento de Ciências Exatas/UFLA, Caixa Postal 3037, CEP: 37.200-000 - Lavras, MG.
}

ABSTRACT - The objective in this work was to determine the nutritive value of high and low tannin high-moisture sorghum grain silage in horse feeding by means of digestibility. A total of eight crossbred geldings at the age of six years and an average body weight of $330 \mathrm{~kg}$ were used in a complete randomized design with samples replicated on the same animals. The test-diets consisted of the ensiled high and low tannin sorghum grains replacing $30 \%$ of the dry matter of the reference diet, constituted exclusively by hay. The daily dry matter intake was equivalent to $2.0 \%$ of the body weight, so, the test diets were constituted by $30 \%$ of ensiled sorghum grains and $70 \%$ of hay. The digestibility coefficients of the nutrients of the low and high tannin sorghum grain silages were obtained by the difference between the coefficient of digestibility of the nutrients of the reference diet and the test-diets. The values of digestibility of dry matter, energy and protein of the high tannin sorghum grain silage were lower (73.65, 73.65 and $71.33 \%$ ) than low tanin sorghum grain silage (87.70, 87.70 and $82.36 \%)$. The contents of digestible dry matter, digestible protein, digestible starch, digestible neutral detergent fiber and digestible energy were $59.08 \%, 10.63 \%, 71.48 \%, 2.32 \%$ and 3,954 Mcal $/ \mathrm{kg}$ of dry matter of the low tannin sorghum grain silage and 50.58\%, $8.16 \%$, $67.80 \%, 3.72 \%$ and $3,192 \mathrm{Mcal} / \mathrm{kg}$ of the dry matter of high tannin sorghum grain silage, respectively, therefore, only contents of digestible neutral detergent fiber and starch were similar among silages. The use of low tannin sorghum grain silage, an alternative food in formulation of promising diets for horses feeding.

Key Words: digestibility, horse, nutrients, nutrition

\section{Valor nutritivo da silagem de grãos úmidos de sorgo com alto e baixo teores de tanino em equinos}

RESUMO - O objetivo neste trabalho foi determinar, por meio da digestibilidade, o valor nutritivo de silagens de grãos de sorgo de baixo e alto teor de tanino na alimentação de equinos. Foram utilizados oito cavalos castrados sem raça definida com seis anos de idade e $330 \mathrm{~kg}$ de peso corporal em delineamento inteiramente casualizado, com amostras repetidas nos mesmos animais. As dietas-teste foram compostas de grãos de sorgo ensilados de baixo e alto teor de tanino em substituição a $30 \%$ da matéria seca da dieta-referência, constituída exclusivamente por feno. A ingestão diária de matéria seca foi equivalente a 2,0\% do peso vivo, assim as dietas-teste foram compostas de 30\% de grãos de sorgo ensilados e $70 \%$ de feno. Os coeficientes de digestibilidade dos nutrientes das silagens de grãos de sorgo com baixo e alto teores de tanino foram obtidos por diferença entre os coeficientes de digestibilidade dos nutrientes da dieta-referência e das dietas-teste. A digestibilidade da matéria seca, energia e proteína da silagem de grãos de sorgo com alto teor de tanino foi inferior (73,65; 73,65 e 71,33\%) à da silagem de grãos de sorgo com baixo tanino (87,70; 87,70 e $82,36 \%)$ Os teores de matéria seca, proteína, amido, fibra em detergente neutro e energia digestíveis foram, respectivamente de 59,08\%; 10,63\%; 71,48\%; 2,32\% e 3,954 Mcal/kg de matéria seca da silagem de grãos de sorgo com baixo tanino e de 50,58\%; 8,16\%; 67,80\%; 3,72\% e 3,192 Mcal/kg da matéria seca da silagem de grãos de sorgo com alto tanino, portanto apenas os teores de FDN e amido digestíveis foram similares entre as silagens. A utilização da silagem de grãos de sorgo com baixo tanino, um alimento alternativo nas formulações das dietas e promissora na alimentação dos eqüinos.

Palavras-chave: cavalo, digestibilidade, nutrição, nutrientes

Received February 12, 2009 and accepted September 24, 2009.

Corresponding author: augustaromaniello@yahoo.com.br 


\section{Introduction}

The feeding by concentrate feeds is important for the maintenance of health and meeting of the nutrient requirements of the several horse categories. Corn and oats are among the energy containing-grains most utilized in diets of horses but the high prices of those cereals limit their use in the formulation of concentrate diets. Therefore, sorghum grain appears as an option because of its similar nutritive composition and economical feasibility for it possesses lower cost/unit of supplemented energy

The use of high moisture silages in horse production come to corroborate with the search for the reducing of the costs with feeding, as well as for obtaining processed grains resulting into the increase of their nutritive value. The non-processed dry sorghum grain presents a high degree of organization in its sub-cellular components, but, when it is ensiled, it occurs a fall of this structure with endosperm rupture -the protein matrix- releasing free starch granules (Lopes et al., 2001).

According to Lewis (2000), low tannin sorghum grain constitutes a nutritive cereal for horses and can be fed as the only grain in the diet of this type with no harmful effects. There are few works about the use of grain silage in horse feeding. However, Oliveira et al. (2007) evaluated the use of high moisture sorghum grain silages with both high and low tannin contents in the feeding of mares at maintenance compared with those of dry sorghum grain. The diet was composed of 50\% roughage: $50 \%$ concentrate containing sorghum grain as the main energy supplier. Nutrient similarity among the diets constituted by ensiled sorghum and dry low tannin sorghum was found, validating the use of ensiled high moisture low and high tannin sorghum.

In the current literature, there is no information about the digestible nutrient contents of sorghum grain silages. It is important the development of research which give priority to the use of low cost technologies and which will be able to increment the tables with information of the ingredients of the diet formulation programs. The present work is intended to evaluate the nutritive value of silage of low and high tannin sorghum grain silage in horses.

\section{Material and Methods}

The assays were developed in the Sala de Metabolismo de Equinos belonging to the Departamento de Zootecnia/ Universidade Federal de Lavras. It was used eight geldings without defined breed at six years of age and an average body weight of $330 \mathrm{~kg}$.
In a phase previous to the assay, the apparent digestibility coefficients of the nutrients of coastcross hay were determined so to obtain by difference the estimate of the digestibility coefficients of the nutrients of the two genotypes of sorghum grains ensiled with low and high tannin content evaluated in the assays. The animals consumed, daily, the equivalent to $2.0 \%$ of their live weight in dry matter of diet exclusive of coastcross hay, characterizing, this way, the reference diet. This phase lasted twenty days, fifteen days of adaptation and five days of total feces collection.

The sorghum varieties (Sorghum bicolor L. Moench) used for making high moisture grain silages were Sara and BRS-701 for low and high tannin silages, respectively. Their harvest was conducted during the physiological maturation phase, when the grains presented 30.32 and 29.73\% of moisture (M) for the low and high tannin genotypes, respectively. For filling the "bag type" silos, it was used an equipment (BOELTER, model OB 20) to perform the grain grinding. Sieves could not be used because of the moisture present in the grains at the moment of ensiling, therefore the particle size of this material was monitored by determining the average geometric diameter in $8 \mathrm{~mm}$ according to the methodology reported by Zanotto e Bellaver (1996). After grinding, the material was packed in $200 \mathrm{~L}$ barrels duly sealed for a 45 day period. At the moment of opening of the silos, samplings for analysis of the chemical composition of the silages were performed (Table 1).

During the experimental period, the same animals of the preliminary phase were used, that is, eight animals in a completely randomized design with two treatments and four replicates. The diets consisted of the two genotypes of high moisture sorghum grains replacing $30 \%$ of the dry matter in the control diet

The amount of the diet fed to the animals was established according to the recommendations by National Research

Table 1 - Chemical composition of the feeds ${ }^{1}$

\begin{tabular}{lccc}
\hline Nutrient & $\begin{array}{c}\text { Coast-cross } \\
\text { hay }\end{array}$ & $\begin{array}{c}\text { Low } \\
\text { tannin } \\
\text { sorghum } \\
\text { silage }\end{array}$ & $\begin{array}{c}\text { High } \\
\text { tannin } \\
\text { sorghum } \\
\text { silage }\end{array}$ \\
\hline Dry matter (\%) & 90.72 & 67.37 & 68.68 \\
Organic matter (\% DM) & 95.64 & 98.69 & 98.34 \\
Starch (\% DM) & 2.85 & 71.48 & 67.80 \\
Crude protein (\% DM) & 7.67 & 12.91 & 11.44 \\
Fiber neutral detergente (\% DM) & 88.89 & 3.98 & 8.29 \\
Acid detergent fiber (\% DM) & 42.45 & 3.53 & 6.53 \\
Gross energy (Mcal/kgDM & 4.335 & 4.509 & 4.334 \\
\hline 1 Analyses were performed at the Laboratório de Nutrição Animal of the UFLA \\
and Laboratório de Bromatologia of ESALQ/USP.
\end{tabular}


Council (NRC, 2007), aiming to meet the nutrient requirements for maintenance. The daily dry matter intake was equivalent to $2.0 \%$ of live weight with the diets composed of $30 \%$ of ensiled sorghum grains and $70 \%$ of coast-cross hay and with the daily furnishing of mineral salt in the amount of $50 \mathrm{~g}$ for each animal. The diets were fed in four daily meals, at 6:00 a.m., 12:00 p.m., 6:00 p.m. and 0:00 p.m., fifteen minutes after the orts were removed and weighed (Table 2).

The experiment lasted 20 days in which 15 days were for the adaptation of the animals. They were housed in individual $2 \times 3 \mathrm{~m}$ pens with cement floor and feeder for concentrate and salt and "bucket" type drinker but no bedding. After this period, the animals were placed in metabolism cages fitted with plastic buckets for water and mineral salt, feeder frontal and feces collector, in which the total collection was performed for five days. The collections of feces were conducted four times a day at 6:00 a.m., 12:00 p.m., 6:00 p.m. and 0:00 a.m. and the samples of each animal were weighted, homogenized and one sample equivalent to $10 \%$ was taken and then put into labeled plastic bags and stored at $18^{\circ} \mathrm{C}$ for further analyses. Before the start of the experiment, widerange vermifuge was administered in the animals.

At the end of the experimental period, the samples were thawed at room temperature, homogenized for obtaining a composed sample of each animal, from which aliquots equivalent to $10 \%$ were taken, weighted and pre-dried in forced ventilation oven at $60^{\circ} \mathrm{C}$ for 72 hours. After drying, a new weighing was proceeded followed by grinding in a $1 \mathrm{~mm}$ - grid sieve.

The analyses of the contents of dry matter, organic matter and crude protein of the feeds and feces were performed, according to the methodology reported in Silva \& Queiroz (2002) and the components of the cell wall, neutral detergent fiber and acid detergent fiber, determined according to Van Soest et al. (1991) in the Laboratório de Nutrição Animal of the Universidade Federal de Lavras. The determination of starch was conducted according to

Table 2 - Chemical composition of the diets

\begin{tabular}{lcc}
\hline Nutrient & \multicolumn{2}{c}{ Diet } \\
\cline { 2 - 3 } & $\begin{array}{c}\text { Coast-cross hay } \\
+ \text { Low tannin } \\
\text { sorghum silage }\end{array}$ & $\begin{array}{c}\text { Coast-cross hay } \\
+ \text { High tannin } \\
\text { sorghum silage }\end{array}$ \\
\hline Dry matter (\%) & 83.72 & 84.12 \\
Organic matter (\%DM) & 95.64 & 95.5 \\
Starch (\%DM) & 23.44 & 22.34 \\
Crude protein (\%DM) & 9.24 & 8.80 \\
Neutral detergent & & 64.71 \\
fiber (\%DM) & 63.42 & 31.67 \\
Acid detergent fiber (\%DM) & 30.77 & 4335 \\
Gross energy (Mcal/kg MS) & 4387 & \\
\hline
\end{tabular}

Macrae \& Armstrong (1968) in the Bromatology Laboratory of the Animal Science Department of ESALQ-USP. The values of gross energy of the feeds and feces were determined by means of an adiabatic calorimeter (Parr Instruments Co).

The contents of digestible dry matter, digestible protein, neutral detergent fiber, digestible acid detergent fiber, digestible starch and digestible energy of the silages were obtained by using the equations by Matterson et al. (1965). The apparent digestibility coefficients of dry matter and of the nutrients of the test diets were computed by the equations proposed by Church (1993).

The results of the digestibility coefficients of the nutrients of the diets were submitted to the analysis of variance of Statistical Analysis System (SAS, 2000) and the means compared with Tukey test at $5 \%$ of probability.

\section{Results and Discussion}

The coefficient of digestibility of dry matter, crude protein, gross energy and neutral detergent fiber differed among the diets with higher values and the diet made up of coast-cross hay and low tannin high moisture sorghum grain silage $(\mathrm{P}<0.05)$, nevertheless, the digestibility coefficient of starch was similar among the diets (Table 3).

There are few works in the literature about the use of high moisture cereal silages in horse feeding, however, Oliveira et al. (2007), found similarity among the digestibility coefficients of dry matter and starch of diets with tannin low sorghum silage and tannin high sorghum silage, with average values of 54.40 and $98.91 \%$, respectively, similar to the average values found in the present work, 56.3 and $98.2 \%$, respectively.

Santos et al. (2002) evaluating foals consuming high moisture corn grain silage in a diet made up of $40 \%$ of roughage and $60 \%$ of concentrate, observed that the digestibility coefficient of gross energy was of $71.1 \%$ by means of replacing $25 \%$ in the dry matter of the concentrate

Table 3 - Apparent digestibility coefficient of the nutrient of the diets containing high moisture sorghum grains in horses

\begin{tabular}{lcccc}
\hline $\begin{array}{l}\text { Apparent } \\
\text { digestibility (\%) }\end{array}$ & $\begin{array}{c}\text { Hay }+ \\
\text { tannin low } \\
\text { sorghum silage }\end{array}$ & $\begin{array}{c}\text { Hay }+ \\
\text { tannin high } \\
\text { sorghum silage }\end{array}$ & Mean \\
\hline Dry matter & $56.97 \pm 1.48 \mathrm{a}$ & $55.64 \pm 0.58 \mathrm{~b}$ & - \\
Gross energy & $55.58 \pm 0.92 \mathrm{a}$ & $53.45 \pm 0.58 \mathrm{~b}$ & - \\
Crude protein & $58.35 \pm 0.40 \mathrm{a}$ & $54.97 \pm 0.5 \mathrm{~b}$ & - \\
Starch & $98.77 \pm 0.04$ & $97.66 \pm 1.04$ & 98.22 \\
Neutral detergent fiber & $58.83 \pm 1.57 \mathrm{a}$ & $51.62 \pm 1.29 \mathrm{~b}$ & - \\
\hline
\end{tabular}

Means with different letters in the same row differ $(\mathrm{P}<0.05)$ from one another by Tukey test. 
by high moisture corn grain silage. The value of the coefficient was higher than the average value of $54.5 \%$ found in the present work about sorghum grain silage. The comparison among the diets should be seen carefully because it is concerned to grains and distinct animal category, moreover, different concentrate: roughage ratios in the diets can have contributed to the discrepancy in the value of energy digestibility.

Negative effect was found in high tannin sorghum silage on the digestibility coefficient of crude protein in the horse diet $(\mathrm{P}<0.05)$. That occurrence was unexpected, for there are reports in the literature about the deactivation of tannins in high moisture sorghum grains ensiled in animal feeding (Mitaru et al. 1984). In addition, Oliveira et al. (2007) found similarity of the digestibility coefficient of crude protein of $65.63 \%$ in mares in maintenance consuming diets made up of coast-cross hay and concentrate (50:50) with low and high tannin sorghum taking part as the chief energy ingredient in the concentrate, when including of 32.5\% in the ingested dry matter. In the present work, the inclusion of high tannin sorghum silage was of $30 \%$ in the dry matter of the diet of the gelding, not accounting for the reduction in the protein digestion by the level of inclusion.

It is speculated that the tannin deactivation mechanism by the water contained in ensiled grains is similar to the reaction occurred in the grains close to physiological maturation stage (Reichert et al. 1980). However, Hibberd (1985) found no reduction in tannin content of the high moisture sorghum grin ensiling containing $30 \%$ of moisture, suggesting that this moisture content of the grains might not have been enough for excellent formation of the silage, with polymerization of tannins, deactivating them. In the present assay, high tannin sorghum grains were ensiled with $29.73 \%$ of moisture and in the paper by Oliveira et al. (2007), the same material was ensiled with 33\% of moisture, suggesting the possibility of the interference from the moisture content of ensiling on tannin deactivation, in addition to the sorghum variety utilized.

The digestibility coefficient of nutrients evaluated in sorghum silages demonstrate that tannin low sorghum silage had better digestibility coefficients $(\mathrm{P}<0.05)$ relative to high tannin sorghum silage (Table 4).

Research evaluating the use of dry high tannin sorghum grains reports reduction in the digestibility of protein and energy, inhibition of microbial and enzyme activity along the digestive tract for several species (Salgado, 1991). In swines, Mitaru et al. (1984) and Patrício et al. (2006) observed that the ensiling of high tannin high-moisture sorghum promoted tannin deactivation, making them similar to low tannin grains. In the present work, the ensiling of high tannin sorghum grains presented no benefit in tannin deactivation and neutralization of their effects on the digestibility of coefficients of nutrients in horses at maintenance. In most research works that evaluate the cereal grain starch digestion in horse nutrition were found values of the digestibility coefficients close to or equal to 100\% (Santos et al., 2002; Gobesso et al., 2004; Fombelle et al., 2004; Al Jassim, 2006; Bailoni et al., 2006; Julliand et al., 2006), similar to that found in the present work.

According to Jobim et al. (2001), the ensiling process increases grain starch digestibility due to starch gelatinization which occurs as temperature and action of the acids produced in ensiling process increase. This process can hydrolyze tannins into sugars, reducing or eliminating their anti-nutritional effects (Van Soet, 1994). Barcellos et al. (2006) cite that the ensiling of high moisture grains increases starch digestion by the breakdown of the protein and crystalline structures of starch.

Campos et al. (2003) found that the presence of tannins in sorghum silages did not influence neutral detergent fiber degradation in ruminants. Nevertheless, Oliveira et al. (2007) verified that increased tannin content in the diet interfered negatively in neutral detergent fiber digestibility in mares at maintenance similar to that found in the present work, with the lowest digestibility coefficient of neutral detergent fiber in the diet containing tannin high sorghum silage in relation to the diet with tannin low sorghum silage $(\mathrm{P}<0.05)$.

The digestible nutrient contents in the high moisture low and high tannin sorghum grain silages proved to be satisfactory (Table 5), mainly because the digestible energy content of $3954 \mathrm{Mcal} / \mathrm{kg}$ DM of the tannin low silage which showed a value higher than that of sorghum grain of $3750 \mathrm{Mcal} / \mathrm{kg}$ DM according to NRC (2007). The digestible energy content of high moisture high tannin sorghum grain silage is a little less, that is, $3192 \mathrm{Mcal} / \mathrm{kg}$ DM. The contents of the other digestible nutrients proved similar to that of the un-ensiled sorghum grain.

Table 4 - Apparent digestibility coefficient of the nutrients of high-moisture low and high tannin sorghum grain silages in horses

\begin{tabular}{lcc}
\hline Apparent digestibility (\%) & \multicolumn{2}{c}{ High moisture sorghum grain silage } \\
\cline { 2 - 3 } & Low tannin & High tannin \\
\hline Dry matter & $87.70 \pm 0.91 \mathrm{a}$ & $73.65 \pm 3.99 \mathrm{~b}$ \\
Gross energy & $87.70 \pm 0.82 \mathrm{a}$ & $73.65 \pm 1.04 \mathrm{~b}$ \\
Crude protein & $82.36 \pm 1.43 \mathrm{a}$ & $71.33 \pm 1.60 \mathrm{~b}$ \\
Starch & 100.00 & 100.00 \\
Neutral detergent fiber & $58.37 \pm 4.67 \mathrm{a}$ & $44.93 \pm 5.37 \mathrm{~b}$ \\
\hline
\end{tabular}

Means with different letters in the same row differ $(\mathrm{P}<0.05)$ from one another by Tukey test. 
Table 5 - Digestible nutrient of high moisture high and low tannin sorghum grain silages in horses

\begin{tabular}{lcc}
\hline Apparent digestibility & \multicolumn{2}{c}{ High moisture sorghum grain silage } \\
\cline { 2 - 3 } & Low tannin & High tannin \\
\hline Dry matter (\%) & $58.08 \pm 0.61 \mathrm{a}$ & $750.58 \pm 2.74 \mathrm{~b}$ \\
Energy (Mcal/kg) & $3954 \pm 0.37 \mathrm{a}$ & $3192 \pm 0.05 \mathrm{~b}$ \\
Protein (\%) & $10.63 \pm 0.18 \mathrm{a}$ & $8.16 \pm 0.18 \mathrm{~b}$ \\
Starch (\%) & 71.48 & 67.80 \\
Neutral detergent fiber (\%) & $2.32 \pm 0.19 \mathrm{~b}$ & $3.72 \pm 0.45 \mathrm{a}$ \\
\hline
\end{tabular}

Means with different letters in the same linha differ from one another by Tukey test $(\mathrm{P}<0.05)$

Santos et al. (2002), evaluating the high moisture corn grain silage in foals reported values of the digestible nutrients of dry matter, energy, protein, starch and NDF of 58.09\%, 3.667Mcal/kgDM, 4.94\%, 70.54\% and 356\% respectively. These results differ from several studies that demonstrate the superiority of corn relative to sorghum for horses. In general, sorghum grain presents value of the digestible nutrients from 92 to $96 \%$ of the values of corn in horses.

Therefore, considering the good results of digestibility and the advantages of sorghum grain as compared with corn, the low tannin high moisture grain silage can be considered a more viable option in relation to corn in horse diets.

Regarded to the use of tannin high sorghum silage, one should be careful about the amount to be fed to horses due to the negative effect on protein digestibility and lower digestible energy content limiting its inclusion in the diets to a level bellow $30 \%$.

\section{Conclusions}

The contents of digestible dry matter, digestible protein, digestible starch, digestible NDF and digestible energy of high moisture tannin low sorghum grain silage are 59.08\%, 10.63\%, 71.48\%, 2.32\% and $3954 \mathrm{Mcal} / \mathrm{kg} \mathrm{DM}$, respectively and, of the high- moisture high tannin sorghum grain silage are $50.58 \%, 8.16 \%, 67.80 \%, 372 \%$ and $3192 \mathrm{Mcal} / \mathrm{kg}$ DM, respectively.

Use of high moisture tannin low sorghum grain silage is promising in horse feeding, becoming an alternative feed in diet formulation.

\section{Acknowledgements}

To Capes for the grant of the scholarship during my Master course.

To Professor Raimundo Vicente de Souza.

To Animal Scientist Lucas Bernardo Nascimento.
To undergraduate students of Animal Science, Thiago Sergio de Andrade and Vinícius Antonio Baptista Oliveira. To the employee Cláudio Borges de Oliveira.

\section{References}

AL JASSIM, R.A.M. Supplementary feeding of horses with processed sorghum grains and oats. Animal Feed Science and Technology, v.125, p.33-44, 2006.

BAILONI, L.; MANTOVANI, R.; PAGNIN, G. et al. Effects of physical treatments on the resistant starch content and in vitro organic matter digestibility of different cereals in horses. Livestock Science, v.100, p.14-17, 2006.

BARCELLOS. L.C.G.; FURLAN, A.C.; MURAKAMI, A.E. Avaliação nutricional da silagem de grãos úmidos de sorgo de alto ou de baixo conteúdo de tanino para frangos de corte. Revista Brasileira de Zootecnia, v.35, n.1, p.104-112, 2006.

CAMPOS, W.E.; SATURNINO, H.M.; SOUSA, B.M. et al. Degradabilidade in situ da silagem de quatro genótipos de sorgo com e sem tanino, II - Fibra detergente neutro, fibra detergente ácido, hemicelulose e celulose. Arquivo Brasileiro de Medicina Veterinária e Zootecnia, v.55, n.4, p.450-453, 2003.

COSTA, C.; ARRIGONI, M.D.B.; SILVEIRA, A.C. et al. Silagem de grãos úmidos. In: SIMPÓSIO SOBRE NUTRIÇÃO DE BOVINOS, 7., 1999, Piracicaba. Anais... Piracicaba: Fundação de Estudos Agrários Luiz de Queiroz, 1999. p.69-88.

CHURCH, D.C. The ruminant animal - Digestive physiology and nutrition. Hardcover: Waveland Pr. Inc. Publisher, 1993. $564 p$.

FOMBELlE, A.; VEIGA, L.; DROGOUL, C. Effect on diet composition and feeding pattern on prececal digestibility of starches from diverse botanical origins measured with mobile nylon bag technique in horses. Journal of Animal Science, v.82, p.3625-3634, 2004.

GOBESSO, A.A.O.; TOSI, H.; SPERS, A. Determinação da digestibilidade aparente de diferentes concentrados para equinos. In: CONGRESSO DE ZOOTECNIA, 14., Angra do Heroísmo, Açores. Anais... Angra do Heroismo: Congresso de Zootecnia, 2004. p.18-19.

HIBBERD, C.A. Effect of sorghum grain variety and reconstitution on site and extent of starch and protein digestion in steers. Journal of Animal Science, v.61, n.3, p.702-712, 1985.

JOBIM, C.C; REIS, R.A. Produção e utilização de silagem de grãos úmidos de milho.In: In: REUNIÃO ANUAL DA SOCIEDADE DE ZOOTECNIA, 38., 2001, Piracicaba. Anais... Piracicaba: Fundação de Estudos Agrários Luiz de Queiroz, 2001. p.912-927.

JULLIAND, V.; De FOMBELE, A.; VARLOUD, M. Starch digestion in horses: the impact of feed processing. Livestock Science, v.100, p.44-52, 2006.

LEWIS, L.D. Nutrição clínica eqüina: alimentação e cuidados. São Paulo: Roca, 2000. 710p.

LOPES, A.B.R.; BERTO, D.A.; MUNIZ, M.H.B. et al. Silagem de grãos úmidos de milho para suínos na fase inicial dos 8 aos $30 \mathrm{~kg}$. Boletim da Indústria Animal, v.58, n.2, p.181-190, 2001.

MACRAE, J.C.; ARMSTRONG, D.G. Enzyme method for determination of linked glucose polymers in biological materials. Journal of Agriculture Science, v.19, p.578-581, 1968.

MATTERSON, L.D.; POTTER, L.M.; STUTZ, M.W. The metabolizable energy of feeds ingredient for chickens. Storr: The University of Connecticut, Agricultural Experiment Station, 1965. 11p. (Research report, 7).

MITARU, B.N.; REICHERT, R.D.; BLAIR, R. Improvement of the nutritive value of high tannin sorghums for broiler chickens by high moisture storage (reconstitution). Poultry Science, v.62, n.10, p.2065-2072, 1983. 
MITARU, B.N.; REICHERT, R.D.; BLAIR, R. Nutritive value of reconstituted sorghum grains for weanling pigs. Journal of Animal Science, v.58, n.5, p. 1211-1215, 1984.

NATIONAL RESEARCH COUNCIL - NRC. Nutrient requirements of horses. 6.ed.rev., Washinton, D.C.: National Academies Press, 2007. 341p.

OLIVEIRA, K.; COSTA, C.; FAUSTINO, M.G. et al. Valor nutritivo e estudo cinético do trato digestivo de dietas contendo grãos secos ou silagem de grãos úmidos de sorgo de baixo e alto tanino para equinos. Revista Brasileira de Zootecnia, v.36, n.6, p.1809-1819, 2007.

PATRICIO, V.M.I.; FURLAN, A.C.; MOREIRA, I. et al. Avaliação nutricional da silagem de grãos úmidos de sorgo de alto ou de baixo conteúdo de tanino para leitões na fase de creche. Revista Brasileira de Zootecnia, v.35, n.4, p.1406-1415, 2006.

REICHERT, R.D.; FLEMING, S.E.; SCHWAB, D.J. Tannin deactivation and nutritional improvement of sorghum by anaerobic storage of $\mathrm{H}_{2} \mathrm{O}$, $\mathrm{HCL}$ or $\mathrm{NaOH}$-treated grain. Journal of Agriculture and Food Chemistry, v.28, n.4, p.824-829, 1980.

ROONEY, L.W.; PFLUGFELDER, R.L. Factors affecting starch digestibility with special emphasis on sorghum and corn. Journal of Animal Science, v.63, n.3, p.1607-1623, 1986.
SALGADO, J.M. Estudio comparativo de cinco metodos para la determincion de taninos en sorgo. Revista Cubana de Ciencia Avícola, v.18, p.167-170, 1991.

SANTOS, C.P.; FURTADO, C.E.; JOBIM, C.C. et al. Avaliação da silagem de grãos úmidos de milho na alimentação de equinos em crescimento: valor nutricional e desempenho. Revista Brasileira de Zootecnia, v.31, n.3, p.1214-1222, 2002.

SILVA, D.J. QUEIROZ, J.S. Análise de alimentos (Métodos químicos e biológicos). 2.ed. Viçosa, MG: Universidade Federal de Viçosa, 2002. 235p.

STATISTICAL ANALYSIS SYSTEM - SAS. SAS user's: guide statistics. Cary: 2000. 211p.

SULLINS, R.D.; ROONEY, L.W. Physical changes in the kernel during reconstitution of sorghum grain. Cereal Chemistry, v.48, n.1-6, p.567-575, 1971.

VAN SOEST, P.J.; ROBERTSON, J.B.; LEWIS, B.A. Methods for dietary fiber, neutral detergent fiber, and nonstarch polysaccharides in relation to animal nutrition. Journal of Dairy Science, v.74, p.3583-3597, 1991.

ZANOTTO, D.L.; BELlAVER, C. Método de determinação da granulometria de ingredientes para uso em rações de suínos e aves. Concórdia: Embrapa Suínos e Aves, 1996. p.1-5. (Comunicado Técnico, 215). 